\title{
Rainwater Harvesting for Campus Student Center: A Sustainable, Community-Orientated Senior Design Project
}

\author{
Dr. Shanon Reckinger \\ Assistant Professor, Department of Mechanical \\ Engineering \\ Fairfield University \\ Fairfield, CT 06824 \\ shanon.reckinger@fairfield.edu \\ Andrew Jackowitz \\ Senior, Department of Mechanical Engineering \\ Fairfield University \\ Fairfield, CT 06824 \\ andrew.jackowitz@student.fairfield.edu
}

\author{
Joseph Bocchino \\ Senior, Department of Mechanical Engineering \\ Fairfield University \\ Fairfield, CT 06824 \\ joseph.bocchino@student.fairfield.edu
}

\author{
John Perry \\ Senior, Department of Mechanical Engineering \\ Fairfield University \\ Fairfield, CT 06824 \\ john.perry@student.fairfield.edu
}

\begin{abstract}
A team of three mechanical engineering senior undergraduate students and one faculty member designed and installed a rainwater harvesting system in the University's student center. After an extensive analysis of the piping system, the team was able to use existing rain leaders and piping to move all the rainwater from the third floor patio to a mechanical room located on the first level of the building. In the mechanical room, the piping system was redesigned to route the collected water into a large storage tank. From the tank, the rainwater was pumped into the irrigation line and used to water a large portion of the campus lawns and greenery. In addition, the system incorporated an overflow feature, a drainage line, a new pump, a flow meter to track water usage (which was previously never tracked at the University), a design where regular flushing of the system is automatic, and a maintenance plan. The harvested rainwater could also potentially be used to fill up the University watering trucks to water the flowers, shrubs, and greenery that covers the $\mathbf{2 0 0}$-acre campus. Students found that this community-based project opened their eyes to sustainability, the environment, and was rewarding work.
\end{abstract}

Index Terms - Sustainability, Rainwater Harvesting, Community-Based Projects, Student Capstone Engineering Projects.

\section{Motivation}

\section{Community-Based Projects}

It has been shown that participation in community-based (or service-based) learning activities enhances the design process for engineering students. ${ }^{12}$ An MIT study also found that key aspects of successful community-based projects include having concrete and realistic short-term goals, collaborating with a solid community partner, and seriously considering implementation from the beginning. ${ }^{3}$ The project discussed here incorporated these aspects into the overarching vision of the project. 
First, the goal of the project was to design and implement a rainwater harvesting system in a building on campus. Since the project was part of a senior design class, the time frame was two semesters, starting in September and ending in April. The team wanted to not just design a system, but actually install it so that their work could serve their University community. Therefore, the first stage of the project was to do a thorough study of all the buildings on campus with the University's Associate Vice President of Facilities Management, in order to find the ideal location for the system. This allowed the team to work to achieve concrete and realistic short-term goals.

Second, the team chose to work with a solid community partner, their own University community. The mechanical engineering faculty member who led the project built strong relationships with Facilities Management and the Faculty Campus Sustainability committee in the summer prior to the start of the course. This collaborative effort had invested interest for all parties involved, which ultimately contributed to the success of the project.

Third, implementation was at the forefront of the project from the beginning. Often times senior design teams are not able to reach an end product or finalized system. When student teams work with a real system that is used by a community on a daily basis, it forces the team to follow through with the entirety of their plans. In the end, it was this reality that ensured that the system would be implemented in a safe, timely, and professional manner.

Other community-based project initiatives have found that these projects provide the students with crucial skill sets that are needed for their future careers. The Engineering Projects in Community Service (EPICS) program at Purdue University was designed with the goal of providing students with three different skills. These three skills include professional skills, awareness of the many issues affecting any engineering project (ethical, legal, environmental, etc.), and the ability to work with people from many different backgrounds and in many social settings. ${ }^{4}$ An effective way of teaching students these skills is to have them work on communitybased projects where they are practicing these skills directly, which is exactly what the project presented here did.

\section{Domestic Projects}

Community-based, service-based, and/or service learning oriented senior design or capstone student projects are becoming more prevalent in engineering education 56789101112 . However, the majority of the projects are focusing on international service work and there seems to be a lack of domestic projects available for students. While the international component provides the students with a wealth of knowledge and invaluable abroad experience, it is also important for students to serve their own communities too. Whether it be recognizing a need in their own community or simply giving back to the community that has provided so much to them, these types of community-based projects are also important.

\section{Integrating Sustainability}

It is important to integrate sustainability and sustainable design into education ${ }^{13}$. Therefore, in addition to focusing the project on a domestic, community-based effort, the project theme was to improve the sustainability of the University campus. Before choosing a rainwater harvesting system, the faculty member explored various sustainable project ideas by meeting with various people across campus to determine potential concepts. Several different options were provided 
to the student team including light harvesting, working on a component of the Jesuit's residence's geothermal system, or designing and prototyping a rent-a-bike system. The students chose to design a rainwater harvesting system, which was a great way to improve sustainability on campus.

\section{Project InTRODUCTION}

As the urbanization in our country transforms the landscape of our cities, towns, and universities, storm water runoff is degrading our water supply. With technological and innovative advances in recent years, storm water in more modern and developed areas is routed to nearby water bodies. Even with these efforts, rainwater is not sufficiently or efficiently managed where it naturally falls. When this storm water runoff is routed to other areas it picks up trash, bacteria, metallic particles and other unwanted pollutants from the urban landscape. Over time, this way of managing storm water can degrade water quality, cause erosion and flooding, leading to damage of natural habitats, properties, and local infrastructure. ${ }^{14}$

In recent years, the University has stressed the importance of green initiatives and sustainability on campus. The University community has taken steps over the past few years to move the University towards an eco-conscious and eco-friendly environment. Campus initiatives such as the installation of a cogeneration power plant in 2007 and the green construction of the Jesuit residence in 2010 are two recent examples of this continuing initiative. The cogeneration power plant, a combined heat and power (CHP) plant, cleanly and efficiently generates power and thermal energy while reducing campus wide emissions of major greenhouse gases, garnering the EPA's 2010 Energy Star CHP Award. The University has also recently replaced all student used washers and dryers with Energy Star® products, saving an estimated 449,000 gallons of water since their installation in 2010. Meanwhile, the recently raised Jesuit residence boasts a closed loop geothermal heating and cooling system, a rooftop garden that can absorb up to 95\% of rainfall, and sustainable bamboo flooring. ${ }^{15}$ With these green steps comes more responsibility for the administration, faculty, staff, and most importantly, the students. Before the rainwater harvesting project, the University did not have any type of rainwater harvesting system on campus. With substantial yearly rainfall totals in the local area, a rainwater harvesting system reuses otherwise wasted runoff rainwater, alleviates environmental strain from excess rainwater runoff, reduces unnecessary potable water usage for irrigation purposes, and continues with the University's green and sustainable initiatives, creating a more environmentally conscious campus.

\section{Project Overview}

The senior design team designed, built, and implemented a rainwater harvesting system on the campus of the University. The team consisted of three senior, undergraduate mechanical engineering majors at the university, and was led by an assistant professor in the department of Mechanical Engineering. The system harvests rainwater runoff from the Barone Campus Center's (BCC) fourth floor roof and third floor patio area. Using current rain leaders and existing piping in the BCC, the rainwater is collected in a large storage tank, which was installed in a mechanical room located on the first level of the BCC. The existing piping system was utilized and altered so that the rainwater runoff flows into the storage tank. From the tank, the rainwater is pumped to the irrigation line and then used to water the lawn and greenery nearby. 
The existing rain leader directs the rainwater outside the building, therefore not utilizing this water for non-potable purposes. The harvested rainwater can also be used to fill up the University watering trucks, which water flowers, shrubs and greenery all over the 200-acre campus. In addition to the rainwater harvesting system, the team also researched other green infrastructure to potentially implement in the vicinity of the BCC. These include the planting of native trees, shrubs and plants and forming a rain garden in the area of the irrigation system. Future plans could also include installation of permeable pavement in the building's parking lot along with the expansion of the harvesting system to serve numerous parts of campus with further rainwater management and storage. However, for the work presented here, the focus will be the initial BCC rainwater harvesting system.

The BCC was found to be the most suitable location for implementing the rainwater harvesting system. With the large patio area surrounding the third level of the building, the amount of water collected would be most substantial. By utilizing some of the current rain leaders and existing piping, the total cost of the project is reduced since the implemented system would be re-routing the rainwater as opposed to creating an entirely new system, which would have to be implemented to the building plan. After touring and measuring the mechanical room site (See Figures 3) it was found that there was sufficient room for a tank (1,100 gallons) and rerouting the water from the rain leaders to a tank is feasible. Furthermore, there was sufficient room in the site to use a pump to route this water from the tank into the irrigation system. The team designed the system so that both rainwater or city water could flow through the tank and into the irrigation system. Also, the entire system can be drained and cleaned, easily.

The student team and the project advisor see this rainwater harvesting system as just the beginning for the University. This project has potential for growth with many buildings and independent irrigation systems on campus that can be tapped into similarly. The proposed system saves the University money by reducing its annual town water usage and it is also in line with the University's Green Sustainability Initiative.

In order to meet the overall goals of the project, which is to create a more sustainable irrigation system on the University campus through the implementation of a rainwater harvesting system, team members outlined specific methods for reaching this goal:

- Use existing rainwater leaders to capture and store rainwater

- Install filtering systems to comply with the EPA's Water Reuse Standards ${ }^{16}$

- Tank design will comply with town building standards ${ }^{17}$

- Safe tank weight of up to 20,000 lbs when completely full with water

\section{BACKGROUND}

In order to better understand the concept behind a rainwater harvesting system like the one the team implemented, a review of literature and prior work was done. The team found patents as simple as a single tank with a complicated system that combined the inlet and outlet flow of the tank into one single location. And complicated systems like one that captured and stored harvested rainwater in the walls of a home or other building, doubling the function of the system as both a rainwater harvesting system as well as serving as a natural insulation for the building, reducing energy consumption in two ways. Of the literature reviewed, the most applicable and useful patents are discussed below. 
Published in 2006, one patent provides details on the use of two tanks for rainwater harvesting $^{18}$. This gave the team a different perspective on how to use two tanks if the need for this alternate design arises or if the addition of another tank were to be considered for future work. The design itself is similar to the team's design, with the most prevalent difference being the use of a dry well for overflow. The master tank closely mirrors the team's design and demonstrates the ability for slave tanks to be attached to the master. This reinforces the idea that the system will be easy to expand if needed. The second tank would simply be connected at the bottom (for filling) and the top (for overflow). The rest of the system remains the same.

Published in 2009, the next patent found is for a custom rainwater harvesting tank ${ }^{19}$. The design incorporates inlet valves, outlet valves, a float valve, and a pump. The team's initial design was similar to this patent, yet different enough to where this patent showed that the team's main concept will work, but the components would have to be altered in order to stay within budget and make the system more user-friendly. The problem with the system designed in this patent was that the components were bundled together making maintenance more difficult that needed. This system described is a more complicated system that combines the inlet and outlet flow of the tank into one single location. The few adjustments made to a system similar to this will be an ideal candidate for the team's final design.

Published in 2009, the last patent provides details on the use of a rainwater harvesting system that stores rainwater within building walls and other structural components ${ }^{20}$. By capturing and storing the rainwater within the structure of the building, this design discussed in this patent serves a dual purpose of rainwater collection for reuse in addition to providing insulation for the structure in the form of the water. Some of the downsides of this system are the complexity of installation along with the building and construction issues that arise. Any structural problem in the building becomes more complex and the system would have to be drained whenever construction and regular structural maintenance to the building was necessary. A system like this would be difficult to incorporate into an existing structure, which is the team's plan at the BCC, and is not feasible at this time. However, this patent was useful in considering future system designs for other future campus construction projects.

The idea of capturing rainwater and using it for other means has been an idea for centuries now. ${ }^{21}$ At first, the water was captured for irrigation needs and used to water crops. That idea is still the main use for rainwater in many areas. The idea presented here is similar because the water harvested will be used for watering the grass around campus.

As a society water is used for almost everything and because it is such a valuable resource, it is in our best interest to use it wisely. Water harvesting is important to discuss for many reasons, one being a growing interest in certain areas of the globe. In some parts of the United States there are infrequent rain patterns causing droughts and other environmental issues. ${ }^{22}$ Collecting rain water to do a simple task such as watering the grass can decrease the amount of water used from a conventional "tap" and save money over time. The main downside to these systems is the amount of time that it takes to get a return on the initial investment. ${ }^{23}$ In theory, these systems are a great idea because they store the small amount of water that a particular region gets. However, in actuality the water that is captured is only a fraction of what is needed. The key to making a collection system efficient is sizing the tank and catchment area to the amount of rainfall in the regional area while also keeping in mind how much water is going to be needed to do the intended job. ${ }^{24}$ 
Rainwater harvesting is a concept that can only work in certain areas because of rainfall data. In order to have a functioning system the amount of water used has to be less than the amount stored to ensure enough water for the system. If the amount of water used is more than the stored amount then it must be augmented with another water source. A major problem arises here because the places that have another water source are not in dire need of the water, and the places that do not have another water source do need the water. This problem makes collecting rainwater very site specific.

After some research about historical rainfall data in our area the team decided that it would be suitable for a collection system that would be capable of irrigating the grass. In conjunction with the patents that were found the team was confident that the project would be a success because of all the prior work that had been done to show the importance of collecting rainwater.

\section{ANALYSIS}

Although the system implemented does not have a tremendous economic savings, it has potential to be expanded. With data shown in Table 1, taken from the US Department of Commerce, expected rainfall in the catchment area can be calculated based off of the local area. ${ }^{25}$

TABLE 1

\begin{tabular}{cc} 
AVERAGE MONTHLY AND ANNUAL RAINFALL IN LOCAL AREA & ${ }^{25}$ \\
\hline Month & Average Rainfall (in.) \\
\hline January & 3.28 \\
February & 2.67 \\
March & 3.83 \\
April & 3.56 \\
May & 3.60 \\
June & 2.90 \\
July & 3.10 \\
August & 3.25 \\
September & 3.18 \\
October & 3.17 \\
November & 3.21 \\
December & 3.09 \\
\hline Yearly & $\mathbf{4 3 . 5 8}$ \\
\hline
\end{tabular}

The team obtained blueprints from University's Facilities Management to measure the catchment area; in addition, site visits were made to measure the catchment areas. The catchment area that the system will be drawing from is $1,000 \mathrm{ft}^{2}$. Table 1 provides the average rainfall for the region, taken from the local airport. The amount of water that the proposed system will harvest each year is approximately 16,188 gallons, which was calculated based off of the square footage of the catchment area and the approximate rainfall from April-November (the only period when irrigation is being done). Assuming a 90\% efficiency rating for the system, which is a typical efficiency rating for a system of this kind, a yearly rainwater harvest figure can be assumed to be around 14,569 gallons, a yearly savings of $0.05 \%$ in water usage and $\$ 51.14$.

The team has also obtained figures from the University concerning the amount the school pays the local water company, which comes out to $\$ 3.51$ for every 1000 gallons of water used. 
The University uses approximately 2,853,000 gallons of water in the BCC yearly. This results in a yearly cost of water usage in the BCC of $\$ 10,014$.

Using this project as a springboard, the University plans to install a weather station on campus, possibly on the BCC. This will provide the University with more accurate data for these calculations and for future data collection that can be uploaded daily to the University online Energy Dashboard system. This system is already in place and monitors the energy usage in each dorm room in the newer dormitory buildings. With this weather station, the system will be able to have more accurate data on environmental savings and savings for the University.

Although the current savings are not significant, there is plenty of room for expansion. If the catchment area was expanded to include the fourth floor patio area, the total catchment area would increase to $48,538 \mathrm{ft}^{2}$. Following the same calculation, the amount of water collected yearly would increase to 1,205,713 gallons with cost savings for the University of $\$ 4,232$ per year, which is $42 \%$ of the yearly water consumption in the BCC. The correlation is simple enough: the more tanks and reservoirs that the campus can implement, the greater the campus wide catchment area becomes and the more water the University can harvest and use.

The storage tanks required for such a system would be substantial. In order to calculate the tank size the process below is used:

- Baseline volume: 1 foot wide by 1 foot long by $1 / 12$ th of a foot high $=0.0833 \mathrm{ft}^{3}$

- Conversion factor from $\mathrm{ft}^{3}$ to gallons: $1 \mathrm{ft}^{3}=7.48052$ gallons

$\circ \therefore$ every $1 \mathrm{ft}^{2}=0.62313$ gallons for 1 " of rainfall

- With $90 \%$ efficiency, this equates to 0.5608 gallons for every $1 \mathrm{ft}^{2}$ with a 1 " rainfall

○ $\therefore 0.5608 *$ Roof Area $*$ Rainfall $=$ Total Rainwater Captured

This gives the equation $0.5608 * 48,538 \mathrm{ft}^{2} * 1$ " rainfall $=27,220 \mathrm{gal}$. While a 27,220 gal modular rainwater cistern is possible, had this been planned while the building was in the design phase it could have been incorporated into the structure of the building itself. By building a 27220 gal pit below the building out of concrete rather than purchasing a modular system, significant savings could be achieved.

\section{Design Constraints and Engineering Standards}

For the team's project, there were several prominent design constraints. The first and most important one was that the tank would fit into the room. Once the tank size was finalized, the next constraint was the pump. The system had to be able to pressurize the water to the necessary pressure for the irrigation system to work. Without the necessary pressure the sprinkler heads would not raise. A 1 hp pump was determined to have the necessary power (this is compared to the former pumps power of $0.5 \mathrm{hp}$ ) in order for the system to work. With the most pressing constraints out of the way, the lesser constraints could be dealt with. The overflow for the tank had to be 1.5 times the size of the inlet, which meant a 6in overflow. Next up was the city water line could not be contaminated, which was dealt with by installing a solenoid valve so the water would not backflow. The city water line is also above the tank, and by height the water cannot travel up the line. The final constraint that was dealt with was that the system had to be capable of being turned off for the winter, and the rain leader continuing its operation as normal. This 
was overcome by installing two 4in valves that direct the water either to the tank, or on its normal path.

There were few standards to deal with since the water is a non-potable use. As for building standards the only important one that was contended with was the walkway space. There had to be $3 \mathrm{ft}$ (width wise) of walkway space around one side of the tank. This was accomplished with ease as there is approximately $4 \mathrm{ft}$ of space with the tank in place.

\section{Concept Analysis}

In order to better design the system, the team considered three independent concepts. It is important to note that all three concepts were considered for a system implementation at the University's BCC location. During the early stages of the project, the team considered several site locations for the system, including Campion Hall and the DiMenna-Nyselius Library; however the BCC was the most feasible location for the system. After deciding on the BCC location for the system, the team then considered three separate concepts: Concept $\mathrm{A}-\mathrm{a}$ single tank, two pump system; Concept B - a single tank, single pump system; and Concept C - a dual tank, single pump system. Table 2 shows Concepts A, B and C in more detail.

TABLE 2

TABLE OF CONCEPT ANALYSIS, WHICH SHOWS WHY CONCEPT C WAS CHOSEN

\begin{tabular}{lccccccc}
\hline & \multicolumn{2}{c}{ CONCEPT A } & \multicolumn{2}{c}{ CONCEPT B } & \multicolumn{2}{c}{ CONCEPT C } \\
\hline & Importance & $\begin{array}{c}\text { 1 Tank 2 } \\
\text { Pumps City } \\
\text { water not }\end{array}$ & Score & $\begin{array}{c}\text { 1 Tank 1 } \\
\text { Pump City } \\
\text { water not }\end{array}$ & Score & $\begin{array}{c}\text { 1 Tank 1 } \\
\text { Pump City } \\
\text { water }\end{array}$ & Score \\
\hline Price & 10 & 2 & 20 & 4 & 40 & 4 & 40 \\
Simplicity of & 6 & 3 & 18 & 5 & 30 & 8 & 48 \\
Simplicity of & 10 & 2 & 20 & 4 & 40 & 8 & 80 \\
Proximity to & 4 & 10 & 40 & 10 & 40 & 10 & 40 \\
Piping & 4 & 6 & 24 & 6 & 24 & 4 & 16 \\
\hline Totals & & \multicolumn{7}{c}{$\mathbf{1 2 2}$} & & $\mathbf{1 7 4}$ & & $\mathbf{2 2 4}$ \\
\hline
\end{tabular}

The Design Plan

\section{Location}

The University sits in a suburban setting, covering 200 acres of land with plenty of green area. As mentioned, the site location is the campus center, referred to as the BCC. A raw aerial view of the site is shown in Figure 1a. Figure 1b shows a view from the outside of the BCC looking at the outer, gray wall of the mechanical room. The tank will be located in the mechanical room, oriented directly behind the light post in the Figure $1 \mathrm{~b}$ view. The green area in front of the BCC building shown in this figure is an ideal place for implementation of additional green infrastructure in the future, such as a rain garden in the form of year round greenery, along with being a suitable place for a possible small reservoir to be built to increase the system's catchment and storage area. Figure 2 shows a modified aerial view. The red area shown is the third floor patio area that will serve as the system's catchment area. The dark green area shown is the area that contains the irrigation system underground that will use the harvested rainwater. 


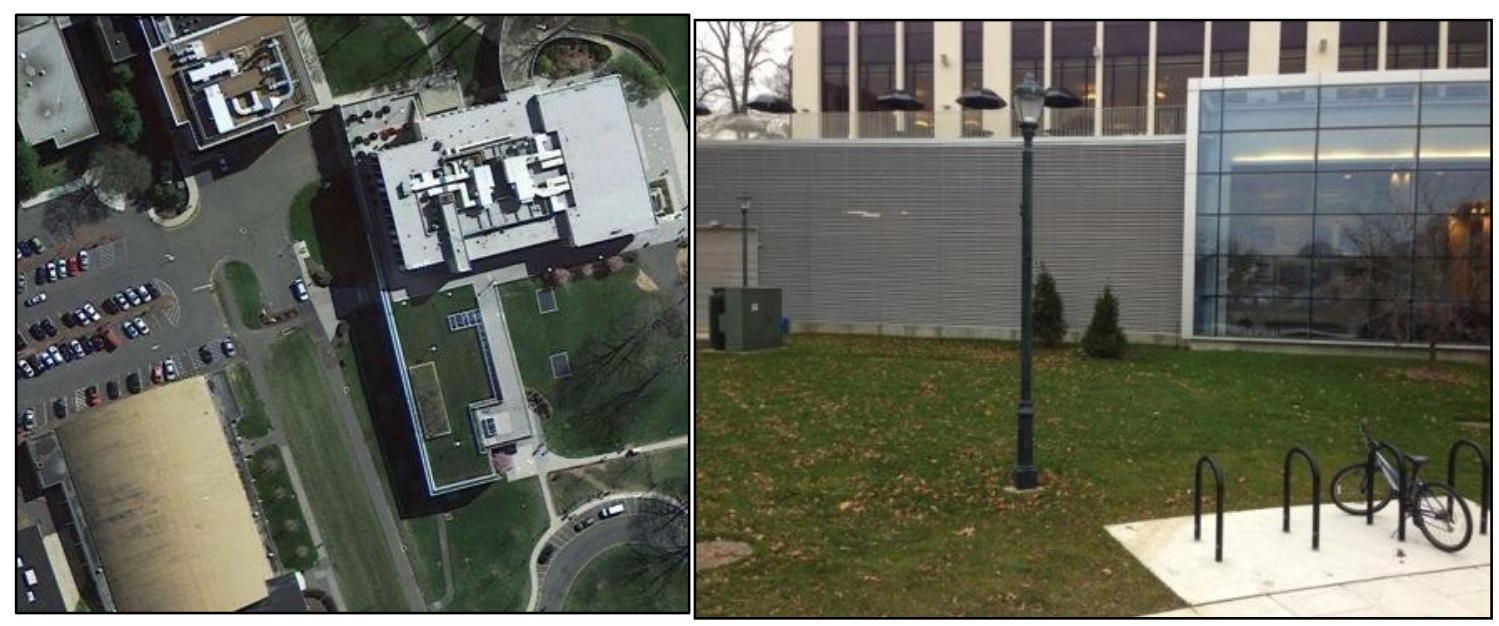

FIGURE 1

AERIAL VIEW OF THE SITE (A, LEFT) AND PEDESTRIAN LEVEL VIEW OUTSIDE THE SITE (B, RIGHT)

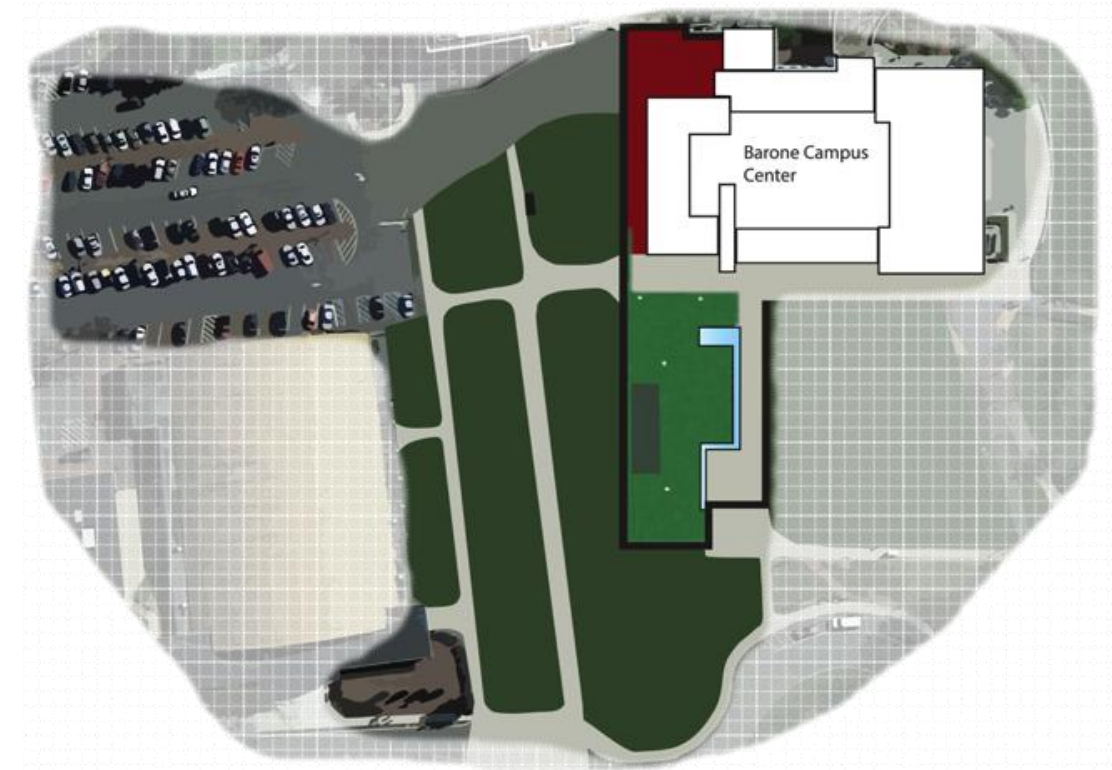

FIGURE 2

AERIAL VIEW OF THE SITE (MODIFIED)

Figures $3 \mathrm{a}$ and $3 \mathrm{~b}$ show photos of the mechanical room site location taken from inside the room, prior to installation. Figure 3 a shows the black rain leader that the system eventually harvested water from. The location of the tank was on the near side of the rain leader, in front of the gray concrete support in Figure 3a. The site was chosen because it had the largest existing catchment area, it was close to the rain leaders and the irrigation pump, and there was sufficient space. 

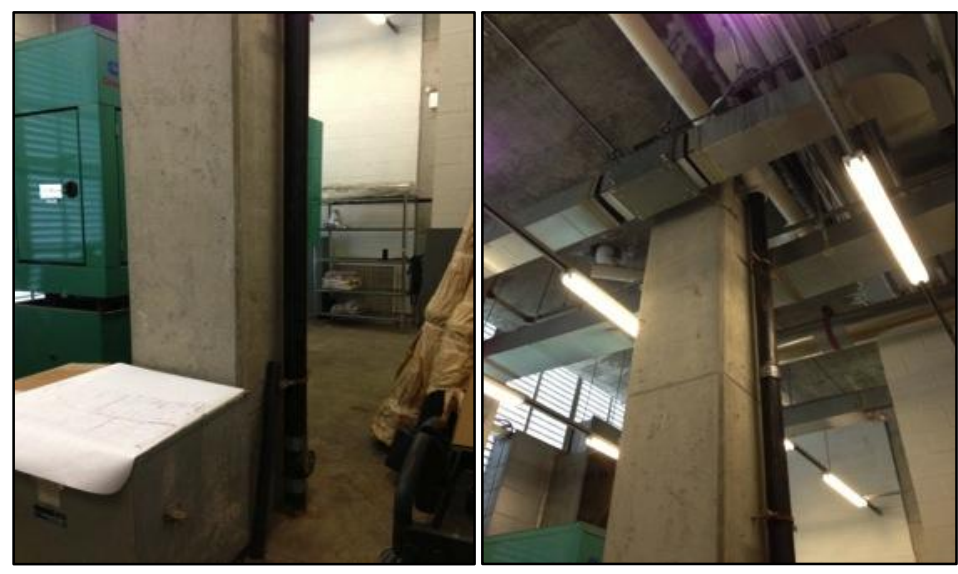

FIGURE 3

PHOTO SHOWING VIEW OF TANK LOCATION (A, LEFT), PHOTO OF RAIN LEADER WHERE BLACK PIPE IS THE MAIN SOURCE OF RAINWATER RUNOFF (B. MIDDLE), AND PHOTO OF CURRENT PUMP FOR IRRIGATION SYSTEM (C, RIGHT)

The black cast iron pipe, which is the master rain leader shown in Figures $3 \mathrm{a}$ and $3 \mathrm{~b}$ is connected to four other rain leaders above it, increasing the catchment area. This rain leader is also in close proximity to a second master rain leader in the adjacent loading dock area, which is also connected to four other rain leaders, doubling the potential catchment area if the two masters are connected. Furthermore, the mechanical room houses the pump (shown in Figure 3c) that powers the irrigation system that the system. This close proximity reduces material cost by decreasing the amount of materials necessary to run the water from the collection tank to the irrigation pump, and eventually to the lawn area. The mechanical room has sufficient space to house a tank of this magnitude and sits on the ground level of the building, which makes the weight of the tank less of a concern. The tank was able to be transported fully assembled into the mechanical room. This was possible because the louvered back wall, facing the outside of building, is fully removable.

\section{The Design}

Based on the review of patents along with relevant research on the basic components of a rainwater harvesting system of this kind ${ }^{26}$, the team was able to determine how best to use existing infrastructure and resources, along with new components and innovative design ideas, to implement the system to the campus center.

The team designed a system that was feasible, reduces water consumption, reduces storm water runoff, and most importantly implements green infrastructure to the University campus. The main component of this rainwater harvesting system is the tank. The tank is a 1,100 gallon polyethylene tank with a diameter of 87 inches and a height of 53 inches. The tank weighs 169 lbf when empty but the system is designed so that the tank will be filled with 200 gallons of water at all times. With this added weight the tank will weigh $1837 \mathrm{lbf}$ at its lowest point. The Computer Aided Design (CAD) model of the system was modeled using SolidWorks ${ }^{\circledR}$ software. A section view of the inside of the tank is shown in Figure 4a and another section view is shown in Figure 4b. 

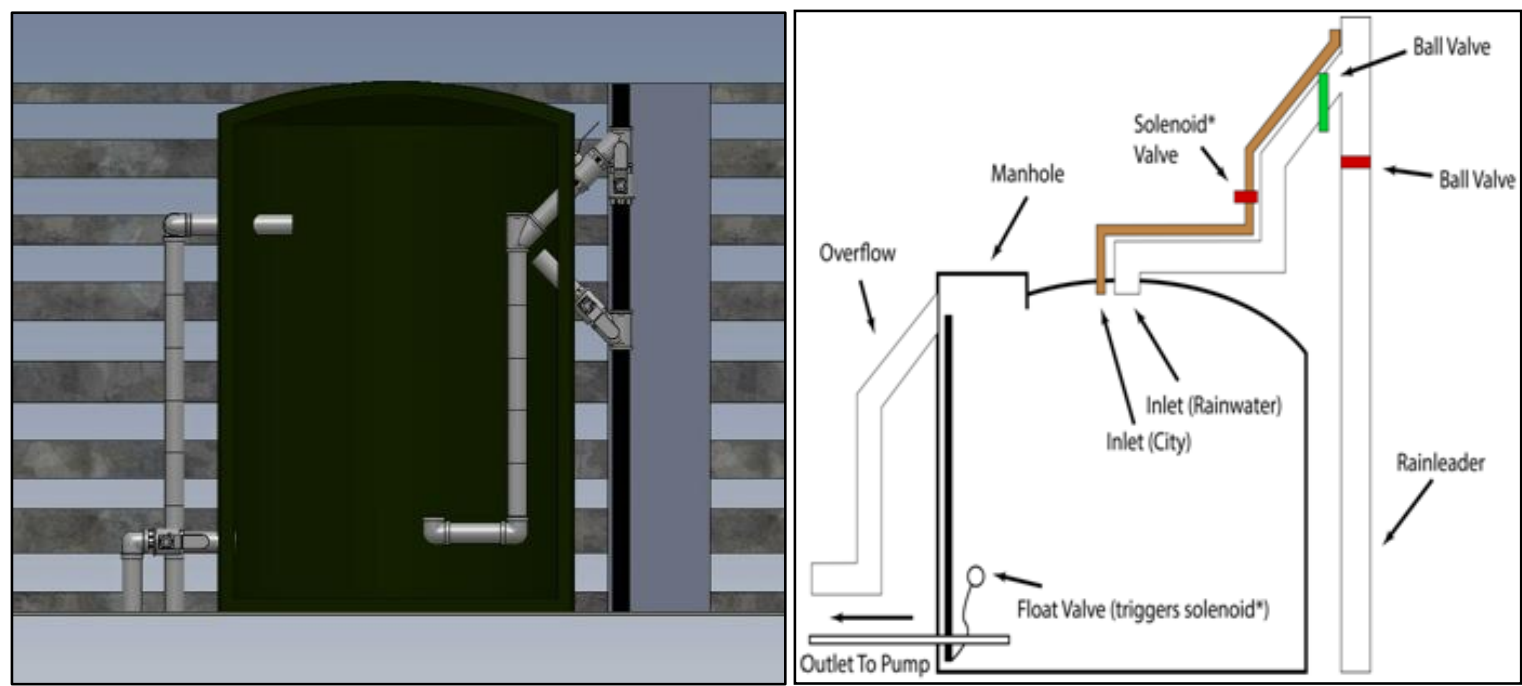

FIGURE 4

CAD SECTION VIEW OF SYSTEM (A, LEFT), DRAWING SECTION VIEW OF SYSTEM (B, RIGHT)

Rainwater from the BCC fourth floor rooftop normally falls to the third floor outdoor patio area where it meets up with rainwater that has fallen directly onto the patio area. Here, this water falls between the cracks of the $2 \mathrm{ft}$. $\mathrm{x} 2 \mathrm{ft}$. concrete tiles on the patio and is then directed to a rain leader by way of a sloped rubber gradient that is situated immediately under the tiles. Upon reaching a rain leader, the water then flows down until reaching the ground. The team's rainwater harvesting system used Polyvinyl Chloride (PVC) piping connected to this rain leader to redirect this rainwater to the inlet of the tank. Upon reaching the inside of the tank, the rainwater flows down near the bottom to be released to the tank for storage. As shown in Figure $4 \mathrm{a}$, the team planned to implement a $U$ shape design for the inlet, however, the team went with the design approach in Figure 4b. The system's current and functioning design fills the tank with the town water supply in order to keep the tank filled at 200 gallons at all times. This function is controlled by the float valve seen above in Figure $4 \mathrm{~b}$. The treated town water contains chlorine and other cleaning agents to help naturally clean the tank continually while it's being used.

Once the tank has accumulated water, the current irrigation pump will pump the water out of the tank by using a single direction flow controller installed inside of the PVC piping that will run from the tank exit to the pump inlet. Specifically, the exit of the tank will begin inside the tank with tubing or piping that will have a floating ball valve (see Figure $4 \mathrm{~b}$ ) attached to the piping that will control the flow of water out of the tank.

Upon being pumped out of the tank, the water will flow horizontally towards the back wall of the mechanical room, level with its height at the exit of the tank. The piping leads the water down to the floor of the room, level with the height of the pump. From here, the water is pumped to the irrigation system located in the area discussed above and shown in Figure 5. 


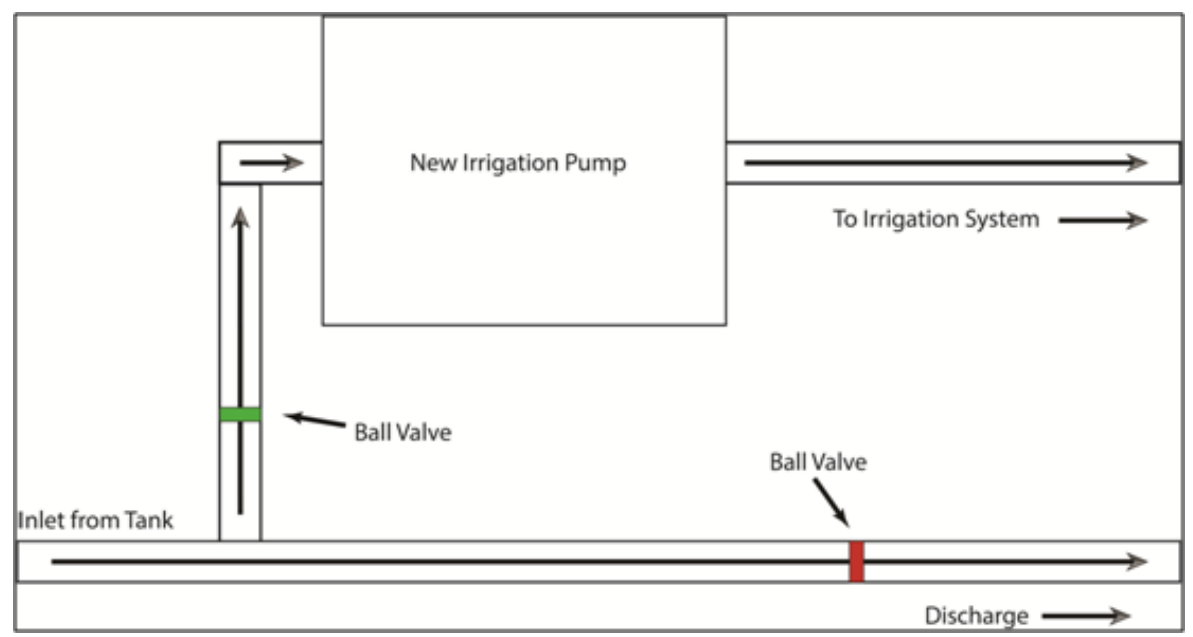

FIGURE 5

TANK TO IRRIGATION SYSTEM SCHEMATIC

Along with being designed with lack of rainfall in mind, the tank has been designed for the other extreme as well. During periods of heavy rainfall, the team expects the 1,100-gallon tank to fill up and even exceed its capacity. The overflow feature has been designed with this in mind. The overflow piping (see Figures $4 \mathrm{a}$ and $4 \mathrm{~b}$ ) will be able to release water to the outside area of the BCC when water levels in the tank have reached their maximum. The entire system would be able to be drained, cleaned and shut off during the winter months when greenery upkeep is not applicable. A three-dimensional CAD model of the system is shown in Figure 6, an isometric view showing the entire tank and connecting system features.

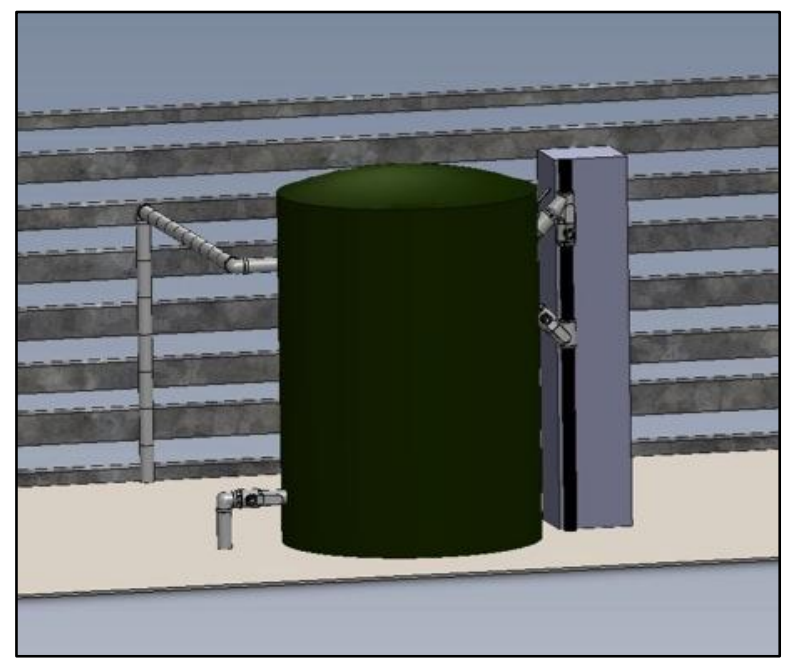

FIGURE 6

3D CAD MODEL OF SYSTEM

Along with the overflow, there are several other features of the system that were designed to tackle and/or circumvent the worst-case scenarios. The 2 " copper pipe to the irrigation pump also serves as a way to manually empty the tank without turning on the pump. Utilizing gravity, the pipe provides an exit for any sediment that may collect in the bottom of the tank by opening the discharge valve. A hose attachment was provided along the column in order to give the 
maintenance faculty a way to clean the inside of the tank. Both the discharge valve and the hose attachment give a way to prevent sediment and other containments from building up. The FMEA below details out several other possible issues.

TABLE 3

FAILURE MODE AND EFFECTIVE ANALYSIS

\begin{tabular}{|c|c|c|c|c|c|c|c|c|c|}
\hline \multirow{2}{*}{ Function } & \multirow{2}{*}{ Failure Mode } & \multirow{2}{*}{ Effects } & \multirow{2}{*}{ Cause } & \multirow{2}{*}{$\begin{array}{l}\text { Control } \\
\text { Method }\end{array}$} & \multicolumn{3}{|c|}{ RPN } & \multirow{2}{*}{\begin{tabular}{|c|} 
Total \\
RPN SCORE \\
\end{tabular}} & \multirow{2}{*}{ Action Plan } \\
\hline & & & & & Severity & Occurrence & Control & & \\
\hline $\begin{array}{l}\text { Moving tank } \\
\text { into } \\
\text { Mechanical } \\
\text { Room }\end{array}$ & $\begin{array}{l}\text { Doesn't fit } \\
\text { through } \\
\text { available } \\
\text { means }\end{array}$ & $\begin{array}{l}\text { Unable to } \\
\text { complete } \\
\text { system } \\
\text { without } \\
\text { significant } \\
\text { costs }\end{array}$ & $\begin{array}{c}\text { Incorrect } \\
\text { measurement of } \\
\text { tank }\end{array}$ & $\begin{array}{l}\text { Design and } \\
\text { implement an } \\
\text { installation } \\
\text { plan }\end{array}$ & 10 & 7 & 2 & 140 & $\begin{array}{l}\text { Remove } \\
\text { louver }\end{array}$ \\
\hline Tank size & $\begin{array}{l}\text { Water level } \\
\text { exceeds tank } \\
\quad \text { limit }\end{array}$ & $\begin{array}{l}\text { Flooding in } \\
\text { the campus } \\
\text { center }\end{array}$ & $\begin{array}{l}\text { Lack of recent } \\
\text { irrigation and/or } \\
\text { large storm }\end{array}$ & $\begin{array}{l}\text { Overflow at } \\
\text { tank limit }\end{array}$ & 7 & 3 & 2 & 42 & $\begin{array}{l}\text { No action } \\
\text { needed }\end{array}$ \\
\hline Check valve & $\begin{array}{l}\text { Backflow of } \\
\text { rainwater into } \\
\text { potable water }\end{array}$ & $\begin{array}{l}\text { Contaminated } \\
\text { potable water }\end{array}$ & $\begin{array}{l}\text { Check valve } \\
\text { failure }\end{array}$ & $\begin{array}{l}\text { Route potable } \\
\text { water through } \\
\text { tank, removing } \\
\text { the need for a } \\
\text { check valve }\end{array}$ & 9 & 3 & 2 & 54 & $\begin{array}{l}\text { No action } \\
\text { needed }\end{array}$ \\
\hline $\begin{array}{l}\text { Sediment in } \\
\text { the tank }\end{array}$ & $\begin{array}{l}\text { Sediment is } \\
\text { being pumped } \\
\text { into irrigation } \\
\text { system }\end{array}$ & $\begin{array}{l}\text { Clogged pump } \\
\text { and/or } \\
\text { sprinkler } \\
\text { heads on lawn }\end{array}$ & $\begin{array}{l}\text { No filter in place } \\
\text { to catch } \\
\text { sediment, lack } \\
\text { of cleaning }\end{array}$ & $\begin{array}{c}\text { Filter on intake } \\
\text { and hose } \\
\text { attachment } \\
\text { next to tank }\end{array}$ & 5 & 5 & 2 & 50 & $\begin{array}{l}\text { No action } \\
\text { needed }\end{array}$ \\
\hline
\end{tabular}

Every gallon of water that is pumped into this irrigation system reduces the University's environmental negative impact. Recall, the existing rain leader directs the rainwater outside the building, therefore utilizing this water for non-potable purposes only such as watering the lawn. The harvested rainwater will also be used to fill up the University watering trucks that are used to water flowers, shrubs and greenery all over the 200 -acre campus.

\section{IMPLEMENTATION AND INSTALLATION}

Fabrication included cutting the existing piping to the irrigation system and installing the piping that needed to go to the tank, then attaching the tank to the irrigation system's pump to complete the circuit. These pipes did not connect to the rain leader, but fed the tank directly. Our system was designed to run the town's water supply through the tank in order to mix with the captured rainwater. The mixing of town and rainwater was used to augment the rainwater supply but also kill any bacteria or disease that may grow in the tank ${ }^{27}$. Legionnaires disease is a potential risk when storing water in tanks. ${ }^{28}$ The bacteria that causes legionnaires disease normally grows in warm water, but mixing it with town water that has been treated with chlorine and other chemicals reduces the risk of it drastically. The team designed it in this fashion because the irrigation system requires much more water daily than the system will capture and in order to 
assure that the tank doesn't run dry the team engineered it so that it will always have a minimum of 200 gallons of water in it. In order to keep 200 gallons of water in the tank at all times a float valve was installed. A float valve floats on top of the water, but as soon as it drops below the 200 gallon mark it triggers the town water to fill the tank to the 200 gallon mark.

The rain leader was removed and a PVC pipe with valves was put into its place. When the valve going to the tank is closed the rain would flow down the rain leader as if the system was never there. If the valve blocking the rain leader is closed and the one leading to the tank is open then all the rain that would normally have drained will be collected in the tank.

Implementation took about four days to get the system operational, once all the parts had arrived. The team did all the work with help and guidance from the facilities staff on campus. Figure 7 shows a photo series documentation the installation process.

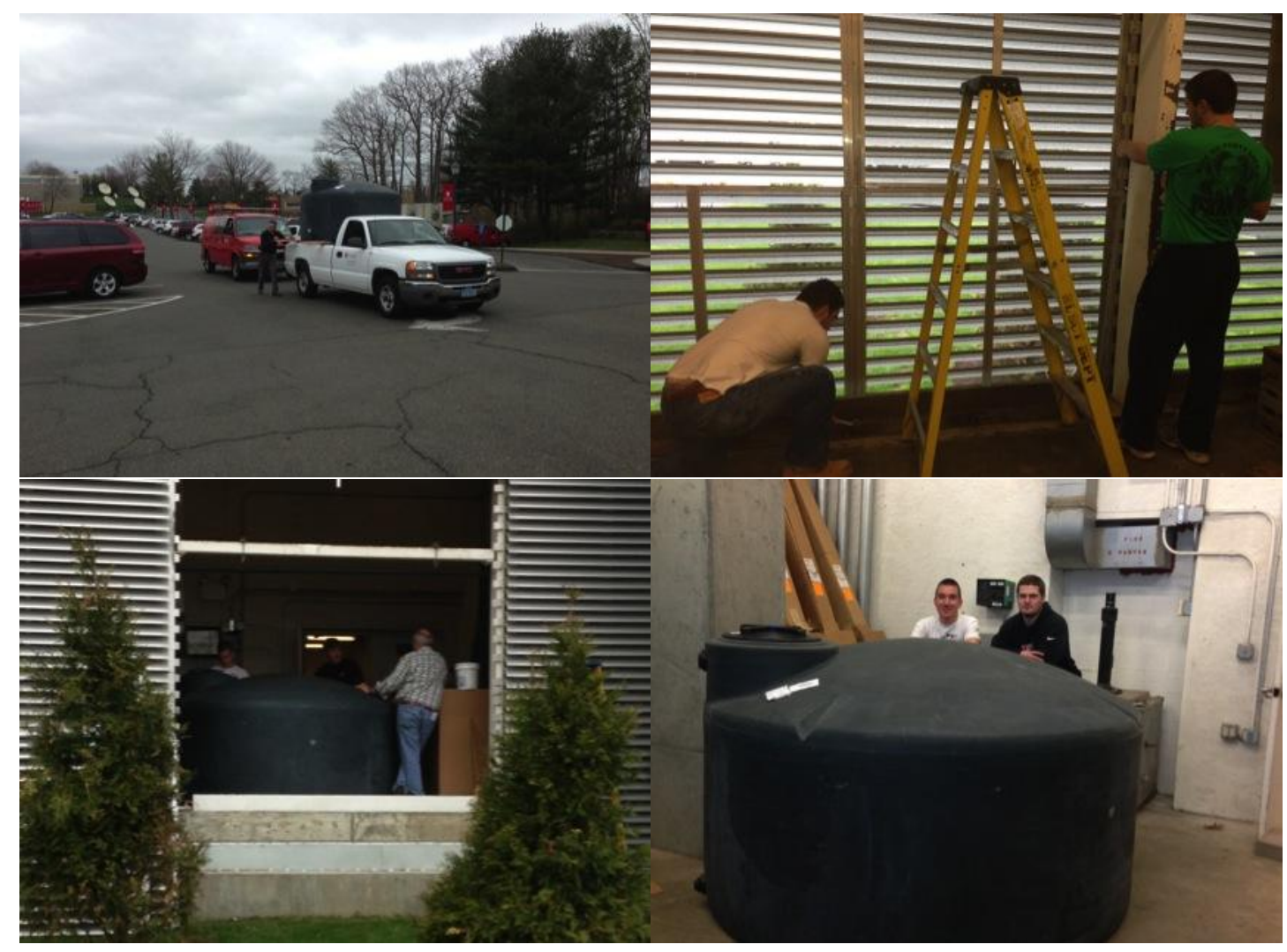

FIGURE 7

The Final Product and Testing

A PHOTO SERIES DOCUMENTED INSTALLATION OF THE RAINWATER HARVESTING SYSTEM 


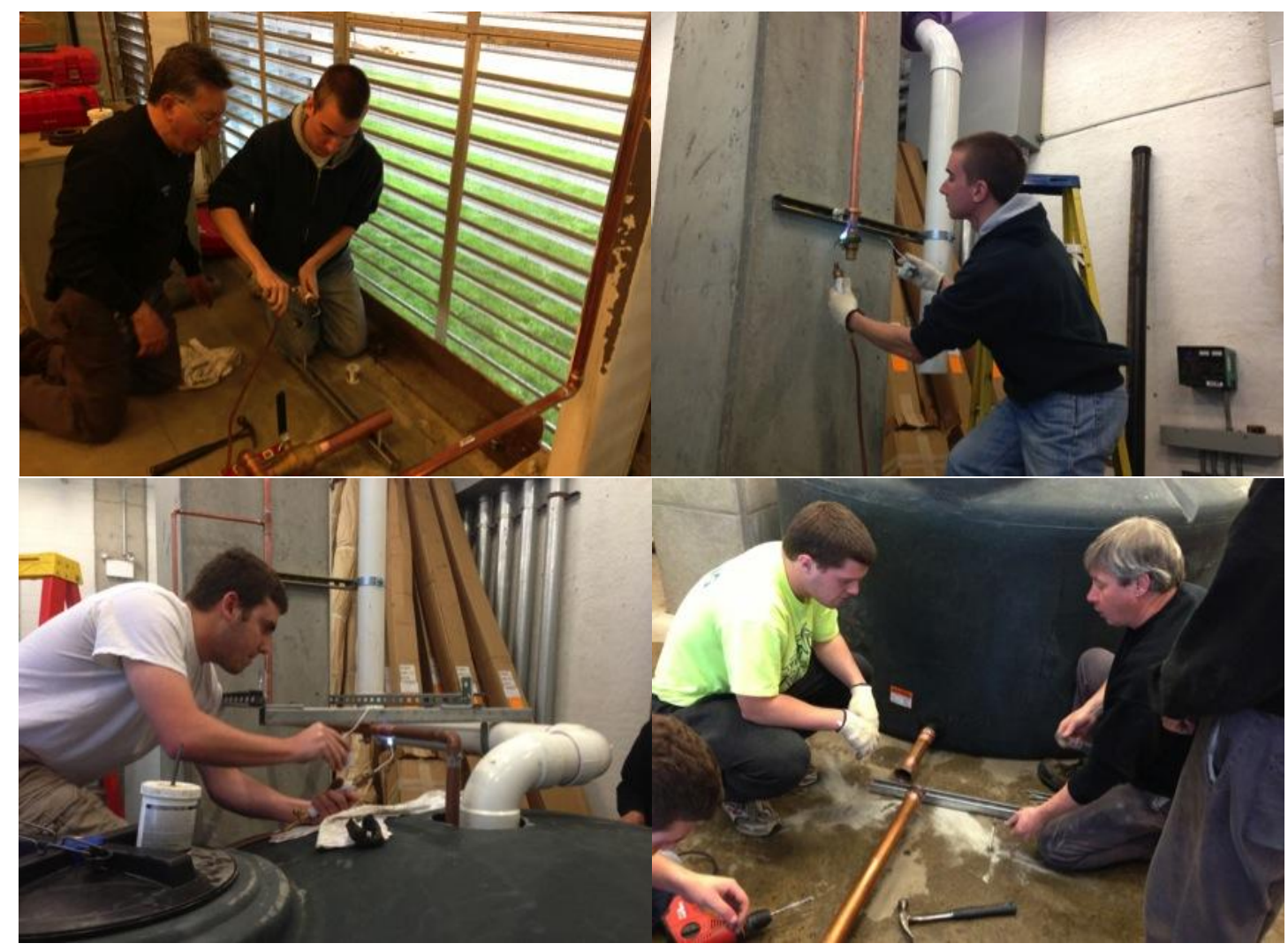

FIGURE 7 (continued)

The Final Product and Testing

A PHOTO SERIES DOCUMENTED INSTALLATION OF THE RAINWATER HARVESTING SYSTEM

The team's system was installed successfully and is $100 \%$ operational. All aspects of the system that the team implemented are working and ready for use. These components include all valves, specifically, the ball valves, solenoid valve, and float valve. The ball valves open and close the various pipes to divert or stop the water. The solenoid valve is triggered by the float valve to ensure that the tank is filled with a minimum of 200 gallons of water. When the system is initially turned on in the spring time the operator will close the valve to the rain leader and open the valve to the tank which will divert the water into the collection tank. The solenoid valve will stay closed as long as there is 200 gallons of water in the tank, but if there is not then the valve will open and the tank will fill to the 200-gallon mark. In order to start the irrigation system, the operator will turn the pump on with the outside control box that the new pump was rerouted to. The overflow pipe was connected to the top of the tank in the event that the solenoid valve fails and the tank overflows. All of these components were tested after implementation, but now the system has been in use for many months with no issues. Also, an electronic gauge with wireless uplink, which could potentially feed data to the University's energy dashboard site, was installed. This data is currently being collected for future analysis. 


\section{FUTURE WORK}

Using the data collected, the system efficiency should be measured using theoretical rainwater harvesting figures from government rainfall data versus what was actually collected. Maintenance personnel who will be using the system will be surveyed to understand any first hand issues they will have encountered or any recommendations that they may have. Their thoughts will be important, as the system will be maintained by Facilities Management on campus. Using the final cost of the system, a post-project cost analysis will be done to analyze how much money the system saves versus how much the system cost.

If the system was connected to the school's energy dashboard where students, faculty, and town residents could see how much water was being used, how much money was being saved, and an overlook at how the system works then it would be much more visible to the community. From this interface the system could be fully automated meaning that any of the valves could be open or closed electronically from a remote location. In order to protect the system, the valves would be power open, meaning that in the case of a power failure, the valves would close shut. A maintenance notification could be given and scheduled from the dashboard and a facilities worker could easily go check out what was happening. If these plans do become part of the system then they could also be implemented onto the other rainwater harvesting systems on campus.

As mentioned, in addition to the rainwater collection system, future teams can also incorporate other green infrastructure in the vicinity of the BCC. These include the planting of native trees, shrubs and plants and forming a rain garden in the area of the irrigation system. This rain garden can serve as a way of reducing the University's storm water runoff by increasing the area's rainwater absorption capabilities. In addition, in the future the University hopes to incorporate current pond and wetland areas into this green initiative through the implementation of additional green infrastructure. Recently, the University was forced to tear up sections of pavement on another side of campus for underground repair work. Upon completion, the University replaced the torn up pavement with permeable pavement. Once the construction calls for the BCC parking lot to be replaced, the University could implement additional green infrastructure. With this project, the team laid the groundwork for future student groups to expand on the goals and initiatives of this project with the installation of other rainwater harvesting systems and green infrastructure on campus.

The future potential for this project is quite significant and preliminary plans and ideas are already in the plans for this project's growth. The University has two untapped resources in the form of two separate ponds on campus that could be used as reservoirs for storing water for irrigation as opposed to tanks which further reduces cost and space restrictions. In future years, this system along with others that will be implemented by that time will be designed to meet the EPA's water reuse standards for potable water, expanding the reach of affected areas of the system. $^{16}$

In addition, every year the entire senior class from the School of Engineering is divided into groups and participates in senior design projects of their choosing. The team sees these future groups as excellent candidates to expand and improve this project each year by adding more rainwater harvesting systems to campus, possibly integrating both of these ponds into harvesting and irrigation systems, and optimizing the design of these systems. In addition, the team sees faculty and students from other academic disciplines getting involved with this project already, broadening the realm of opportunity for academic research and study. 
Over the summer months and in future years, this project can become a platform for crossdiscipline research study. The Chemistry and Biology departments on campus are already involved in the possible testing of lawn, soil, and town water samples along with the harvested water samples post system implementation. The plan is to perform these sample tests in order to gain baseline data for data analysis after the system is in working condition. Furthermore, the Chemistry and Biology departments, along with other departments on campus, will get their students involved in future years for projects and work across disciplines on capstone and research projects.

\section{CONCLUSIONS AND REFLECTIONS}

The project proved to be successful both for the student's learning but also for implementing a sustainable system on the University campus. Additionally, it sparked an interest not only by students and faculty on campus, but the local community and nation organizations recognized the work. The University wrote two different news briefs highlighting the rainwater harvester (both when the grant was offered and when the project was completed). A story was published in the local city newspaper and later the American Society of Engineering Education also picked up the story to send out to their mailing list.

\section{Reflections}

Reflections from the students were gathered based off of reflection-based assessment work in service learning for undergraduate engineering students ${ }^{29}$. Overall, the project had an overwhelmingly positive influence on the student's perception of engineering. Table 3 summarizes some of the reflections and Figure 8 shows the team with their final design. 
TABLE 3

TABLE OF STUDENT'S REFLECTIONS ON THE PROJECT

\begin{tabular}{|c|c|c|c|}
\hline & Student A & Student B & Student C \\
\hline $\begin{array}{l}\text { How did your project } \\
\text { affect the community? }\end{array}$ & $\begin{array}{l}\text { Affected everyone at } \\
\text { the University: } \\
\text { students, faculty, and } \\
\text { the community. }\end{array}$ & $\begin{array}{l}\text { Brought together } \\
\text { students and faculty; } \\
\text { strengthened the } \\
\text { environmental } \\
\text { movement. }\end{array}$ & $\begin{array}{l}\text { SOE students, friends, } \\
\text { LEAF leaders, faculty } \\
\text { all saw the benefit of } \\
\text { our project to the } \\
\text { University. }\end{array}$ \\
\hline $\begin{array}{l}\text { Interested in doing a } \\
\text { similar project again? }\end{array}$ & $\begin{array}{l}\text { Yes, the project } \\
\text { showed what an } \\
\text { impact small projects } \\
\text { can make on a larger } \\
\text { scale vision }\end{array}$ & $\begin{array}{l}\text { Yes. Undoubtedly } \\
\text { worth my time; real } \\
\text { world example of } \\
\text { MEP engineering; } \\
\text { appreciated being } \\
\text { involved in } \\
\text { engineering side plus } \\
\text { construction, } \\
\text { administration, and } \\
\text { contractor side too. }\end{array}$ & $\begin{array}{l}\text { Absolutely. A project } \\
\text { that engaged } \\
\text { administrators, } \\
\text { faculty, student clubs, } \\
\text { and requires } \\
\text { coordination among } \\
\text { these groups has been } \\
\text { a very valuable } \\
\text { learning experience. }\end{array}$ \\
\hline $\begin{array}{l}\text { Did the project } \\
\text { broaden your } \\
\text { perception of the } \\
\text { engineering } \\
\text { profession? }\end{array}$ & $\begin{array}{l}\text { Yes, before I thought } \\
\text { engineers only worked } \\
\text { on complex engine } \\
\text { models or with high } \\
\text { tech equipment. }\end{array}$ & $\begin{array}{l}\text { Yes. A much more } \\
\text { realistic view of } \\
\text { engineering. }\end{array}$ & $\begin{array}{l}\text { Yes. There we } \\
\text { experienced all project } \\
\text { stages and allowed us } \\
\text { to act as engineering } \\
\text { in many various ways. }\end{array}$ \\
\hline $\begin{array}{l}\text { Comments on } \\
\text { working with different } \\
\text { types of people to get a } \\
\text { project completed? }\end{array}$ & $\begin{array}{l}\text { Involves A LOT of } \\
\text { scheduling, time, and } \\
\text { flexibility. }\end{array}$ & As expected. & $\begin{array}{l}\text { We were able to } \\
\text { communicate } \\
\text { efficiently and } \\
\text { effectively with all } \\
\text { types of personnel. }\end{array}$ \\
\hline $\begin{array}{l}\text { Most memorable } \\
\text { aspect? }\end{array}$ & $\begin{array}{l}\text { Turning on the } \\
\text { sprinkler system for } \\
\text { the first time! }\end{array}$ & $\begin{array}{l}\text { Starting up the system } \\
\text { and seeing all } \\
\text { irrigation zones up } \\
\text { and running. }\end{array}$ & $\begin{array}{l}\text { Putting the whole } \\
\text { system together } \\
\text { during the last weeks } \\
\text { of the project with the } \\
\text { Facilities employees. }\end{array}$ \\
\hline $\begin{array}{l}\text { Community-based } \\
\text { project more } \\
\text { impactful than } \\
\text { traditional } \\
\text { engineering project? }\end{array}$ & $\begin{array}{l}\text { Yes, our project } \\
\text { impacted the students } \\
\text { and community } \\
\text { through our service } \\
\text { based project, more } \\
\text { impacting than a } \\
\text { traditional project. }\end{array}$ & $\begin{array}{l}\text { Yes. Not only had a } \\
\text { large impact on } \\
\text { community but green } \\
\text { project garnered } \\
\text { attention on } \\
\text { University's water } \\
\text { use. }\end{array}$ & $\begin{array}{l}\text { Yes. This system is } \\
\text { functional and } \\
\text { currently serving as a } \\
\text { beta site for future } \\
\text { systems. Positive } \\
\text { impact and great } \\
\text { potential. }\end{array}$ \\
\hline
\end{tabular}




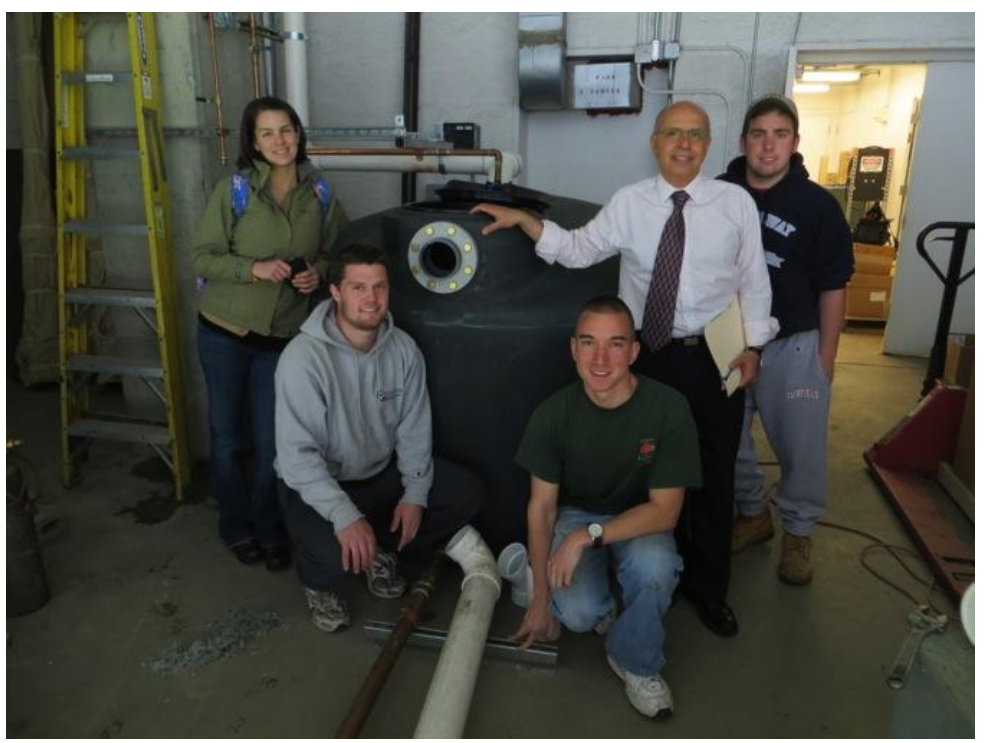

FIGURE 8

A PHOTO OF THE TEAM WITH THEIR FINAL INSTALLATION

\section{Challenges}

A typical criticism of community-based projects in engineering is that they are often criticized for not being "technical" enough. Many of the skeptics value the use of modern technology, inclusion of traditional engineering analysis and theory, and complex nature of the problem over the value of having student projects actually contribute something directly to a community. Rethinking Engineering Education: The CDIO Approach ${ }^{30}$ wrote: "Modern engineers design products, processes, and systems that incorporate technology. Sometimes this is state-of-the-art technology, pushing new frontiers, and creating new capabilities. That is the stuff of startups and breakthrough innovations. However, much of engineering design is performed by applying and adapting existing technology to meet society's changing needs. In most of the world, society is uplifted by broad-based applications of existing technology. Good engineers apply appropriate technology to design." That is to say, "Good engineers observe and listen carefully to determine the needs of the member of society for whom the benefit is intended."

\section{ACKNOWLEDGMENT}

The authors would like to thank the Faculty Campus Sustainability committee and the Department of Facilities Management at Fairfield University for funding this project. A special thanks to David Frassinelli, Associate Vice President for Facilities Management, for the inspiration for the project and all of the support, guidance, and resources. Also, they would like to thank Tom Carr from Plumbers and HVAC Mechanics, who supervised the entire installation of the project. They would also like to thank Dr. Shahrokh Etemad, Chair of Mechanical Engineering and instructor of EG391, the senior design course. Lastly, thanks to Dr. James Biardi, Associate Professor of Biology; Dr. Dina Franceschi, Professor of Economics; Thomas F. Curran, RA, Director of Campus Planning \& Design and Campus Architect; James Fitzpatrck, Assistant Vice President for Student Affairs; the University student club, LEAF (particularly officer Helen Nelson '14); the Proactiv Investment Club's Revolving Green Fund group 
(particularly leader Arturo Watts '14); Dr. Jack Beal, former Dean of the School of Engineering; and all the other students, faculty, and staff at Fairfield University, who supported this project.

\title{
REFERENCES
}

\begin{abstract}
${ }^{1}$ Lemons, Gay, Adam Carberry, Christopher Swan, and Linda Jarvin. "The Effects of Service-Based Learning on Metacognitive Strategies During an Engineering Design Task." International Journal for Service Learning in Engineering, Humanitarian Engineering and Social Entrepreneurship 6, no. 2
\end{abstract} (2011): 1-18.

${ }^{2}$ Padmanabhan, G., and Dinesh Katti. "Using community-based projects in civil engineering capstone courses." Journal of Professional Issues in Engineering Education and Practice 128, no. 1 (2002): 12-18.

${ }^{3}$ Jue, Diana. "Improving the Long-Term Sustainability of Service-Learning Projects: Six Lessons

Learned from Early MIT IDEAS Competition Winners." International Journal for Service Learning in Engineering, Humanitarian Engineering and Social Entrepreneurship 6, no. 2 (2011): 19-29.

${ }^{4}$ Coyle, Edward J., Leah H. Jamieson, and William C. Oakes. "2005 Bernard M. Gordon Prize Lecture*: Integrating Engineering Education and Community Service: Themes for the Future of Engineering Education." Journal of engineering education 95, no. 1 (2006): 7-11.

${ }^{5}$ Marsolek, Michael D., Patrick K. Cummings, Joshua T. Alcantara, Michael Wynne, Luis F. Quintero, Carlos Vallejos, Charles F. Jackels, and Susan C. Jackels. "Wastewater Treatment for a Coffee Processing Mill in Nicaragua: A Service-Learning Design Project." International Journal for Service Learning in Engineering, Humanitarian Engineering and Social Entrepreneurship 7, no. 1 (2012): 69-92.

${ }^{6}$ Thompson, Phillip L., Chris R. Kemly, Amanda Connell, Kathryn V. Nolan, David Jacobs Jr, and Gerald Omar A. Ongoco. "Evaluation of Water Treatment Systems for Medical Clinics." International Journal for Service Learning in Engineering, Humanitarian Engineering and Social Entrepreneurship 7 , no. 1 (2012): 15-27.

${ }^{7}$ Kadlowec, Jennifer, Jess Everett, Hong Zhang, Taylor Purdue, Katelyn Dmitruck, Kevin Ketcho, Kyle Pillion, and Daniel Bouniaev. "Rope Pump Modifications to Reach Greater Depths: A Service Project for Clean Water in The Gambia." International Journal for Service Learning in Engineering, Humanitarian Engineering and Social Entrepreneurship 8, no. 2 (2013): 8-23.

${ }^{8}$ Budny, Dan, and Robert Thomas Gradoville. "International Service Learning Design Projects: Educating Tomorrow's Engineers, Serving the Global Community, and Helping to Meet ABET Criterion." International Journal for Service Learning in Engineering, Humanitarian Engineering and Social Entrepreneurship 6, no. 2 (2011): 98-117.

$* *$ this paper considers how ABET handles service and international experience

${ }^{9}$ Thompson, Phillip L., Sonya Milonova, Meghan Reha, Faisal Mased, and Ian Tromble. "Coil Pump Design for a Community Fountain in Zambia." International Journal for Service Learning in Engineering, Humanitarian Engineering and Social Entrepreneurship 6, no. 1 (2011): 33-45.

10 Heil, Ethan, Duncan Nengwenani, Audrey Raedani, Veronica Gutierrez, Gadisi Nthambeleni, Khuthalani Mathoma, Rachel Brown-Glazner, and Robert Swap. "Student-led, Community Driven Improvement of the Drinking Supply in a Rural Village in South Africa." International Journal for Service Learning in Engineering, Humanitarian Engineering and Social Entrepreneurship 5, no. 1 (2010): 94-110.

${ }^{11}$ Thomas, Brian. "A wind powered, white LED lighting system for the Kibera slum of Nairobi." International Journal for Service Learning in Engineering, Humanitarian Engineering and Social Entrepreneurship 2, no. 1 (2007).

${ }^{12}$ Mehta, Yusuf, and Beena Sukumaran. "Integrating service learning in engineering clinics." International Journal for Service Learning in Engineering, Humanitarian Engineering and Social Entrepreneurship 2, no. 1 (2007). 
**challenge: how much engineering work is actually applied

${ }^{13}$ Al-Khafaji, Karim, and Margaret Catherine Morse. "Learning sustainable design through service." International Journal for Service Learning in Engineering, Humanitarian Engineering and Social Entrepreneurship 1, no. 1 (2006).

${ }^{14}$ EPA Campus RainWorks Challenge Competition Brief, 2012, The United States Environmental Protection Agency, Washington, DC

${ }^{15}$ The Fairfield University Campus Sustainability Committee, n.d, from: http://www.fairfield.edu/green/green_campus.html

${ }^{16}$ The United States Environmental Protection Agency, 2004, "Guidelines for Water Reuse," 625/R04/108.

17 "Code of the Town of Fairfield, Connecticut", 2006, 56.1-11, http://ecode360.com/8187139

${ }^{18}$ Zimmerman Jr, Robert L., Joseph Antocci, and Nigel Pickering. "Rainwater recovery system." U.S. Patent 7,025,076, issued April 11, 2006.

${ }^{19}$ Burke, Edward J.. "Rainwater harvesting tank." U.S. Patent US20090166275 A1, issued July 2, 2009.

${ }^{20}$ Appel, Jennifer. "Method and system for using rain water in buildings" U.S. Patent US20090133754 A1, issued May 28, 2009.

${ }^{21}$ AbdelKhaleq, K. A., and I. Alhaj Ahmed. "Rainwater harvesting in ancient civilizations in Jordan." Water Science \& Technology: Water Supply, 7, no.1 (2007).

${ }^{22}$ Jones, Matthew P., and William F. Hunt. "Performance of rainwater harvesting systems in the southeastern United States." Resources, Conservation and recycling 54, no. 10 (2010): 623-629.

${ }^{23}$ Domènech, Laia, and David Saurí. "A comparative appraisal of the use of rainwater harvesting in single and multi-family buildings of the Metropolitan Area of Barcelona (Spain): social experience, drinking water savings and economic costs." Journal of Cleaner Production 19, no. 6 (2011): 598-608.

${ }^{24}$ Guo, Yipping and Brian W. Baetz. "Sizing of Rainwater Storage Units for Green Building Applications", Journal of Hydrologic Engineering, 12, no. 2 (2007): 197-205.

${ }^{25}$ United States of America Department of Commerce, "Monthly Precipitation Probabilities and Quintiles 1971 - 2000", Climatography of the United States No. 81, Supplement No. 1

${ }^{26}$ Daily, Cado and Cyndi Wilkins, "Basic Components of a Rainwater Storage System", The University of Arizona College of Agriculture and Life Sciences Cooperative Extension, AZ1565, (2012).

${ }^{27}$ Edstrom Industries, Inc., "Chlorination of Drinking Water", (2003).

${ }^{28}$ World Health Organization, URL:

http://www.who.int/water_sanitation_health/hygiene/ships/en/gssanitation6.pdf

${ }^{29}$ Dukhan, Nihad, and Mark R. Schumack. "Reflection-based assessment of service learning in undergraduate engineering." International Journal for Service Learning in Engineering, Humanitarian Engineering and Social Entrepreneurship 5, no. 2 (2010): 32-43.

${ }^{30}$ Crawley, Edward F. Rethinking engineering education: the CDIO approach. Vol. 133. Springer Science+ Business Media, LLC, 2007. 